\title{
Supply Chain Management Untuk Agen Game RTS Menggunakan Hierarchical Finite State Machine
}

\author{
Dihin Muriyatmoko \\ Teknik Informatika, Fakultas Sains dan Teknologi, \\ Universitas Darusalam Gontor, Ponorogo \\ e-mail:dihin@unida.gontor.ac.id
}

\begin{abstract}
Abstrak
Real Time Strategy merupakan salah satu genre dalam permainan komputer yang memiliki ciri khas berupa permainan perang. Permainan yang menarik dan disukai biasanya hampir mendekati dunia nyata manusia. Umumnya pada game yang ada, tidak memiliki distribusi makanan, sehingga menjadikan game kurang manusiawi. Pada model lain pasukan yang kembali dari perang, membutuhkan waktu agar pulih, namun ketika kondisi dimana pemain ingin kembali berperang, energi pasukan belum sepenuhnya pulih, karena itu dibutuhkan suatu metode agar pasokan makanan bisa tepat sasaran. Percobaan ini menggunakan metode Hierarchical Finite State Machine untuk mendesain perilaku agen game RTS dan mengacu pada skema supply chain management agar perilaku agen dalam mendistribusikan makanan mendekati dunia nyata. Penempatan lokasi koordinat agen dirancang mengacu pada skema supply chain dengan pendekatan gravity location model agar menghasilkan posisi koordinat yang optimal sehingga waktu dan biaya dalam distribusi makanan bisa diminimalkan. Hasil pengujian menunjukkan rata-rata penghematan biaya dan waktu masing - masing $52.97 \%$ dan $48.47 \%$.
\end{abstract}

Kata kunci: Supply Chain Management, HFSM, RTS Game

\begin{abstract}
Real Time Strategy is one of the genres in computer games that have a characteristic form of war. The attractive and preferably game usually approach to the real world.

Generally on RTS games do not have food distribution that makes the game less humane. On other models troops was returning from war, need to takes recovered, but when the condition that the player wants to war again, the energy not fully recovered, so need a method that the food supply target is precise..

This experiment using Hierarchical Finite State Machine to design the behavior of agents and refers to the scheme of supply chain management so that the behavior approach to the real world.

Placement agent location coordinates using a scheme of supply chain approach to gravity location coordinates of the model in order to produce an optimal position so that the time and costs in the food distribution can be minimized. The results show the average percentage cost and time savings for $52.97 \%$ and $48.47 \%$.
\end{abstract}

Keywords: Supply Chain Management, HFSM, RTS Game 